\title{
Does morphology have real impact on local and distant recurrences in head and neck cutaneous melanoma?
}

\author{
A.M. Mudunov, M.B. Pak, L.V. Demidov, K.A. Baryshnikov \\ N.N. Blokhin National Medical Research Center of Oncology, Ministry of Health of Russia; \\ Russia, 115478 Moscow, Kashirskoye Hwy, 24 \\ Contact: Maxim Pakmbpak@yandex.ru
}

Introduction. The term "local recurrence" is usually understood as regrowth of a tumor after surgical treatment. The regrowth appears within 3-5 cm from postoperative cicatrix. The causes for such prolonged tumor growth or recurrence of patients with cutaneous melanoma are nonradical surgical treatment as well as satellite or transit metastases that were not removed in-block with primary tumor. A great number of clinical researches, aimed at examination of melanoma, its patterns, anatomical criteria and features of clinical course, gave an opportunity to separate satellite or transit metastases into an independent group. Such metastases are realized inside or subdermally, up to $2 \mathrm{~cm}$ or more than $2 \mathrm{~cm}$ from the primary tumor, yet, not reaching the location of the first regional barrier.

The aim of the study is to define influence of the main prognostic factors such as tumor thickness according to Breslow, the level of invasion according to Clark and the presence of ulceration on the frequency of local recurrence with cutaneous melanoma of head and neck.

Materials and methods. The research involved 174 patients with cutaneous melanoma of head and neck (1995-2014). According to our index of contraction of a skin flap (median $30 \%$ ) the true borders of resection were clearly defined within all the patients. Thereby, 3 groups were identified with the following resection margin: $<0.5 ; 0.6-1.0$ and $>1.0 \mathrm{~cm}$, where followed-up treatment results were analyzed.

Results. Progression-free survival didn't correlate with the size of surgical resection margins. The survival rates were the best with the lowest resection margin under $0.5 \mathrm{~cm}$ (77.3\%) and the worst with the highest resection margin more then $1.0 \mathrm{~cm}(38.7 \%)$. That means that the treatment results don't depend on the width increase of tumor resection margin.

Conclusions. We consider that clear surgical margins for any thickness of cutaneous melanoma of head and neck should be as follows: $<2 \mathrm{~mm}-$ $0.46 \mathrm{~mm}(p=0.13), 2.01-4.00 \mathrm{~mm}-0.58 \mathrm{~mm}(p=0.002),>4 \mathrm{~mm}-0.72 \mathrm{~mm}(p=0.016)$. In our work, the influence of the main prognostic factors, such as tumor thickness according to Breslow, level of invasion according to Clark and ulceration on the frequency of head and neck cutaneous melanoma local recurrences had no impact.

Key words: cutaneous melanoma, head and neck, local recurrence, surgical resection margin, progression-free survival

For citation: Mudunov A.M., Pak M.B., Demidov L.V., Baryshnikov K.A. Does morphology have real impact on local and distant recurrences in head and neck cutaneous melanoma? Opukholi golovy $i$ shei = Head and Neck Tumors 2020;10(3):55-64.

DOI: $10.17650 / 2222-1468-2020-10-3-55-64$

(cc) BY

Влияют ли морфологические признаки на частоту местных рецидивов и отдаленных метастазов при меланоме кожи головы и шеи?

\section{А.М. Мудунов, М.Б. Пак, Л.В. Демидов, К.А. Барышников}

ФГБУ «Национальный медицинский исследовательский центр онкологии им. Н. Н. Блохина» Минздрава России; Россия, 115478 Москва, Каширское шоссе, 24

Введение. Под термином «местный рецидив» обычно понимают повторный рост опухоли после хирургического вмешательства, который возникает в пределах 3-5 см от послеоперационного рубиа. Причины продолженного роста опухоли или рецидива у пациентов с меланомой кожи - нерадикальное хирургическое лечение, а также сателлитные или транзитные метастазы, которые не были удалены единым блоком вместе с первичной опухолью. Многочисленные исследования особенностей биологии меланомы, морфологических критериев ее диагностики и особенностей ее клинического течения позволили выделить в отдельную группу сателлитные и транзитные метастазы, которые реализуются внутри- или подкожно на расстоянии $<2 \mathrm{cм} \mathrm{или}>2 \mathrm{cм} \mathrm{от} \mathrm{пер-}$ вичной опухоли, но не достигая места расположения первого регионарного барьера.

Цель исследования - определить влияние основных прогностических факторов, таких как толщина опухоли по Breslow, уровень инвазии по Clark и наличие изъязвлений, на частоту местных рецидивов при меланоме кожи головы и шеи.

Материалы и методы. В исследовании приняли участие 174 пациента с меланомой кожи головы и шеи, проходившие лечение в 1995-2014 гг. С помощью полученного нами индекса сокращения кожного лоскута (медиана 30 \%) истинные границы резекции были точно определены у всех пациентов. В зависимости от этого были сформированы 3 группы с отступом $<0,5 ; 0,6-1,0$ и $>1,0$ см, в которых проанализированы отдаленные результаты лечения.

Результаты. Безрецидивная выживаемость не коррелировала с величиной хирургического отступа. Она была лучшей при минимальном хирургическом отступе (77,3 \%) и худшей при максимальном отступе $(38,7$ \%), т. е. отдаленные результаты лечения не зависят от ширины хирургического отступа. 
Заключение. С использованием ROC-кривых определены безопасные границы хирургического отступа для меланомы кожи головы и шеи: при толщине меланомы кожи головы и шеи $<2$ мм отступ 0,46мм ( $p=0,13)$, при толщине меланомы 0,58мм - 2,01-4,00 мм ( $p=0,002)$, при толщине меланомы >4 мм - 0,72 мм ( $p=0$,016). В нашей работе такие факторы, как толщина опухоли по Breslow, уровень инвазии по Clark и наличие избязвлений, не влияли на частоту местных рецидивов меланомы кожс головы и шеи, что дает основание утверждать, что уменьшение хирургического отступа действительно не приводит к ухудшению отдаленных результатов лечения.

Ключевые слова: меланома кожи, голова и шея, местный рецидив, край резекции, выживаемость без прогрессирования

Для цитирования: Мудунов А.М., Пак М.Б., Демидов Л.В., Барышников К.А. Влияют ли морфологические признаки на частоту местных рецидивов и отдаленных метастазов при меланоме кожи головы и шеи? Опухоли головы и шеи 2020;10(3):55-64. (На англ.).

\section{Introduction}

Cutaneous melanoma refers to a range of tumors with unexpected clinical outcome. On the one hand, it is connected with the aggressive character of the tumor and severity of prognosis, on the other hand with the possibility of curing of the disease on the stage of local process [1, 2]. Despite the fact that this pathology constitutes not more than $12 \%$ among all malignant skin neoplasms, death rate due to this pathology constitutes more than $75 \%$ among all death occurrences induced by malignant dermal diseases. According to the data from various authors, cutaneous melanoma of head and neck occurs in approximately 20-30\% of cases [3]. Over the past 3 decades there has been a sharp increase in the incidence of cutaneous melanoma disease [4-6]. There were 10454 new cases of cutaneous melanoma patients in the year of 2016 in Russia. From 2006 to 2016 average annual increase of diseased constituted $3.07 \%$ [7]. The peak incidence of diseases is observed in the age group of 60-64.

In Russia, according to the data for the year of 2018, around one third of patients were diagnosed with I-II stages of the disease $-79.2 \%$, and III and IV stages of the disease -10.5 and $8.6 \%$, respectively. However, if one separates I and II stages, the incidence of this disease will not seem so optimistic. Thus patients with "early" cutaneous melanoma (I stage) are detected in approximately 10-12\% of cases, but in a more significant amount of cases - $60 \%$ of patients are exposed with "interim" neoplastic process (II stage), a long-term prognosis of life that cannot be considered satisfactory.

An increase in the incidence of cutaneous melanoma indicates that diagnostic methods for this pathology have improved in recent years, at the same time high mortality from disseminated melanoma is recorded.

The main treatment for primary cutaneous melanoma remains surgical removal. Up till the $50-60$ s of the XX century, most oncologists performed very extensive, ultraradical operations in order to improve treatment results [8]. Most surgeons had no doubt that a narrow melanoma resection would lead to an inevitable recurrence of the disease. In the literature, one could find recommendations for the surgical treatment of primary cutaneous melanoma with resection margin borders from $2 \mathrm{~cm} \mathrm{[9]} \mathrm{to} 15 \mathrm{~cm} \mathrm{[10-14].} \mathrm{At} \mathrm{the} \mathrm{same}$ time, more and more works on clinical trials of a more economical resection began to appear.
Thus, over the past 30 years, the main problem of the surgical treatment of primary cutaneous melanoma all over the world was the question about the size of resection margins [10, 15-21].

Since 19856 prospective clinical researches studying the optimum resection margin borders of primary cutaneous melanoma resection margin of the skin with different tumor thickness have been conducted. It should be pointed out that patients with head and neck cutaneous melanoma were included in only one of such large studies (European Trial French, 1993 (Khayat D. et al.)). According to table 1 it is clear that all researches were conducted more than 10-20 years ago and it was possible to study the question of safe resection margin at any stage of the neoplastic process throughout this time, except for the stage IIC (cutaneous melanoma $>4 \mathrm{~mm}$ thick with ulceration "T4b"), which, according to our data, is the most common in the Russian population due to late diagnosis, and the least studied in prospective randomized studies.

Statistical analysis of the conducted research showed that reducing the boundaries of the resection margin does not lead to increase of the number of recurrences and overall survival rate remains the same in both groups. Thus, the result has always been in favor of an economical resection of primary cutaneous melanoma.

Nevertheless, in 2015 Keith Wheatley and his co-authors carried out a meta-analysis of 6 prospective researches described above. According to the authors, economical resection is not inferior to a wider one; however, "a slight difference does not mean that it does not exist". There were 4233 patients with cutaneous melanoma included in the research, where a wide resection $(3,4$ and $5 \mathrm{~cm})$ was compared to a more narrow one $(1$ or $2 \mathrm{~cm})$. In the result of this systematic overview and meta-analysis a slight worsening of followed-up treatment results was detected [33].

Speaking of followed-up treatment results of cutaneous melanoma, one should notice that life prognosis isn't influenced by safe resection margin. The main morphological factors of primary tumor such as tumor thickness according to Breslow and the presence of invasion [34]. At the same time, the size of the surgical resection margin affects the frequency of local recurrences, reflecting the radical nature of surgical intervention in the area of the primary site [35].

The term "local recurrence" is usually understood as regrowth of a tumor after surgical treatment. The regrowth 
Table 1. Clinical research evaluating the boundaries of resection margin borders for radical removal of primary cutaneous melanoma

\begin{tabular}{|c|c|c|c|c|c|c|}
\hline Research & $\begin{array}{l}\text { Amount } \\
\text { of patients }\end{array}$ & Tumor thickness & $\begin{array}{l}\text { Resection } \\
\text { margin } \\
\text { borders }\end{array}$ & $\begin{array}{c}\text { TNM/AJCC } \\
2009\end{array}$ & Overall survival & $\begin{array}{l}\text { Periodicity } \\
\text { of local } \\
\text { recurrences }\end{array}$ \\
\hline $\begin{array}{l}\text { European Trial French, } \\
1993 \text { (Khayat D. et al.) } \\
{[22,23]}\end{array}$ & 336 & $\leq 2 \mathrm{~mm}$ & $2 v s 5 \mathrm{~cm}$ & I-IIA & 87 and $86 \%$ (10-year) & 13.6 and $20 \%$ \\
\hline $\begin{array}{l}\text { Swedish I MSG Trial } \\
\text { Swedish, } 2000 \text { (Cohn- } \\
\text { Cedermark G. et al., } \\
\text { Ringborg U. et al.) } \\
{[24,25]}\end{array}$ & 989 & $0.8-2.0 \mathrm{~mm}$ & $2 v s 5 \mathrm{~cm}$ & I-IIA & $\begin{array}{l}79 \text { and } 76 \% \\
\text { (5-year) }\end{array}$ & 0.6 and $2.4 \%$ \\
\hline $\begin{array}{l}\text { WHO Melanoma Trial, } \\
1991 \text { (Cascinelli N. } \\
\text { et al., Veronesi U. et al.) } \\
{[26,27]}\end{array}$ & 612 & $\begin{array}{c}\leq 2 \mathrm{~mm} \\
(0.99 \mathrm{~mm} \\
\text { in group } 1 \mathrm{~cm}, \\
1.02 \mathrm{~mm} \\
\text { in group } 3 \mathrm{~cm})\end{array}$ & $1 \mathrm{vs} 3 \mathrm{~cm}$ & I-IIA & $\begin{array}{c}96.4 \text { and } 96.4 \% \\
\text { (10-year) }\end{array}$ & $\begin{array}{c}0.98 \text { and } \\
0.97 \%\end{array}$ \\
\hline $\begin{array}{l}\text { Intergroup Melanoma } \\
\text { Trial Intergroup, } 1996 \\
\text { (Balch C. et al., } \\
\text { Karakousis C.P. et al.) } \\
\text { [28-30] }\end{array}$ & 740 & $\begin{array}{l}1-4 \mathrm{~mm} \\
\text { (average } \\
\text { thickness } \\
1.8 \mathrm{~mm} \text { ) }\end{array}$ & $2 v s 4 \mathrm{~cm}$ & I-IIB & 70 and $77 \%$ (6-year) & 2.1 and $2.6 \%$ \\
\hline $\begin{array}{l}\text { UK Trial BAPS/MSG, } \\
2004 \text { (Thomas J.M. } \\
\text { et al.) [31] }\end{array}$ & 900 & $\begin{array}{l}\geq 2 \mathrm{~mm} \text { (average } \\
\text { thickness } \\
\text { in group } \\
1 \mathrm{~cm}-3 \mathrm{~mm}, \\
\text { in group } \\
3 \mathrm{~cm}-3.1 \mathrm{~mm} \text { ) }\end{array}$ & $1 v s 3 \mathrm{~cm}$ & I-IIC & $\begin{array}{l}32.2 \text { and } 30.9 \% \\
\text { (5-year) }\end{array}$ & $\begin{array}{l}8.27 \text { and } \\
5.64 \%\end{array}$ \\
\hline $\begin{array}{l}\text { Swedish II, } 2005 \\
\text { (Gillgren P. et al.) [32] }\end{array}$ & 1000 & $\begin{array}{c}\geq 2 \mathrm{~mm} \\
(\mathrm{pT} 3, \mathrm{pT} 4)\end{array}$ & $2 v s 4 \mathrm{~cm}$ & I-IIC & $\begin{array}{l}\text { Preliminary findings: } \\
\text { no differences with } \\
\text { 5-year survival detected }\end{array}$ & - \\
\hline
\end{tabular}

appears within $3-5 \mathrm{~cm}$ from postoperative cicatrix. The causes for such prolonged tumor growth or recurrence of patients with cutaneous melanoma are nonradical surgical treatment as well as satellite or transit metastases that were not removed in-block with primary tumor $[1,36,37]$. A great number of clinical researches, aimed at examination of melanoma, its patterns, anatomical criteria and features of clinical course, gave an opportunity to separate satellite or transit metastases into an independent group. Such metastases are realized inside or subdermally, up to $2 \mathrm{~cm}$ or more than $2 \mathrm{~cm}$ from the primary tumor, yet, not reaching the location of the first regional barrier.

We consider it to be necessary to differentiate two following notions - recurrence, which appeared straight in cicatrix, and the realization of satellite or transit metastasis, which is interpreted by many authors as "local recurrence". We believe that it is wrong to consider their presence as a "local recurrence", since they represent a sign of the systemic character of the disease and are classified according to the TNM AJCC $8^{\text {th }}$ edition (2017) in the "N" category [38]. It should be noted that the life prognosis of the patients from both groups is different. In the first case a repeated event is present as a local process as well as other manifestations of the disease may not occur, while in the other case realization of metastasis to regional lymph node of neck takes place and the situation meets the "N2c" criterion, 5-year survival of which does not exceed $40-45 \%$. According to many authors, satellitosis happens due to the phenomenon of "sticking" of melanocytes in lymphatic fissure. The issue of likelihood of the development of satellites on this or that particular area of skin with the realization of metastasis to regional lymph node of neck with various thicknesses of primary melanoma remains unsolved. This would allow a more selective approach to the concept of "wide resection of head and neck cutaneous melanoma", where the issue of economical removal is most relevant.

However, there is another point of view on the nature of relapsing lesions with cutaneous melanoma. This theory is based on paracrine stimulation of the primary tumor of normal melanocytes with their subsequent transformation into tumorous ones (Prof. L.V. Demidov). Such mechanism arises due to the humoral effect of growth factors of the primary tumor, which can circulate throughout the whole body even after the removal of the primary tumor. These factors 
can stimulate the production of the same factors in normal melanocytes, involving an increasing number of normal cells in the process of tumor transformation. Taking this point of view into account, it becomes absolutely clear that such mechanism of a recurrence does not depend on the volume of a removed tissue. In support of this theory, there are a number of individual clinical observations in which a local recurrence occurs simultaneously with remote metastasis. This fact confirms the consistency of existence of paracrine mechanism. However, further study of the pathogenesis of relapsing processes is necessary to confirm this theory.

Thus, it seems interesting to analyze the influence of different factors on the frequency of local recurrences after radical removal of cutaneous melanoma of head and neck.

\section{Materials and methods}

This study is based on retrospective data from 174 patients with head and neck cutaneous melanoma who received treatment at the N.N. Blokhin National Medical Research Center of Oncology in 1995-2014. The age of patients ranged from 18 to 92 years (mean age $54.4 \pm 16.3$ years, median 54 years). When evaluating the results of treatment, depending on the resection margin, it should be also taken into consideration that there is such an issue as a reduction of the skin flap from the moment of resection till the description of it by a pathomorphologist, and there are differences between surgical and pathological resection margins. Due to the fact that the main source of information was the data of histological findings, where the pathomorphological margin was indicated, this circumstance had to be taken into account in order to determine the true boundaries of the resection in the future. Therefore, there was a need to find a method that would objectively restore the original size of the skin flap.

For this reason, we introduced a skin flap reduction index - the amount of tissue volume loss, which is estimated as the reduction in the distance from the edge of the resection to the edge of the tumor before and after surgery and which is expressed as a percentage. A prospective part of the research was performed in the Department of Head and Neck Tumors of the N.N. Blokhin National Medical Research Center of Oncology in 2013-2015. The purpose of the research was to evaluate the skin flap reduction index. The study included 21 patients with a local form of head and neck cutaneous melanoma. 25 skin flaps were examined. The most frequent anatomical localization of the primary lesion was the facial area $-12(48 \%)$ cases. In $8(32 \%)$ cases, the head and in $5(20 \%)$ cases, the neck.

When a skin flap was formed after resection, the distance from the edge of resection margin to the edge of the tumor reduced from 14.1 to $53.3 \%$ and averaged $31.2 \pm 10.7 \%$. Thus, the median contraction of the skin flap was $30 \%$ (fig. 1). It appeared that the skin flap reduction index didn't significantly differ in relation to the location of the tumor and the age of the patients.

The conducted analysis allowed us to calculate the true value of resection margin of all patients in the retrospective group $(n=174)$. We stratificated the main group of patients into 3 subgroups depending on the adjusted value of the resection margin: $<0.5 \mathrm{~cm}, 0.6-1.0 \mathrm{~cm}$ and $>1.0 \mathrm{~cm}$.

The minimal resection margin $(<0.5 \mathrm{~cm})$ was most often used in the group of patients with primary tumor localization in the facial area $-48.9 \%(n=44)$ (compared to hairy part of the head $-20.8 \%(n=11)$ and neck area $-6.4 \%(n=2)$, $p<0.005$ ) (table 2). Surgical margin of $0.6-1.0 \mathrm{~cm}$ was most

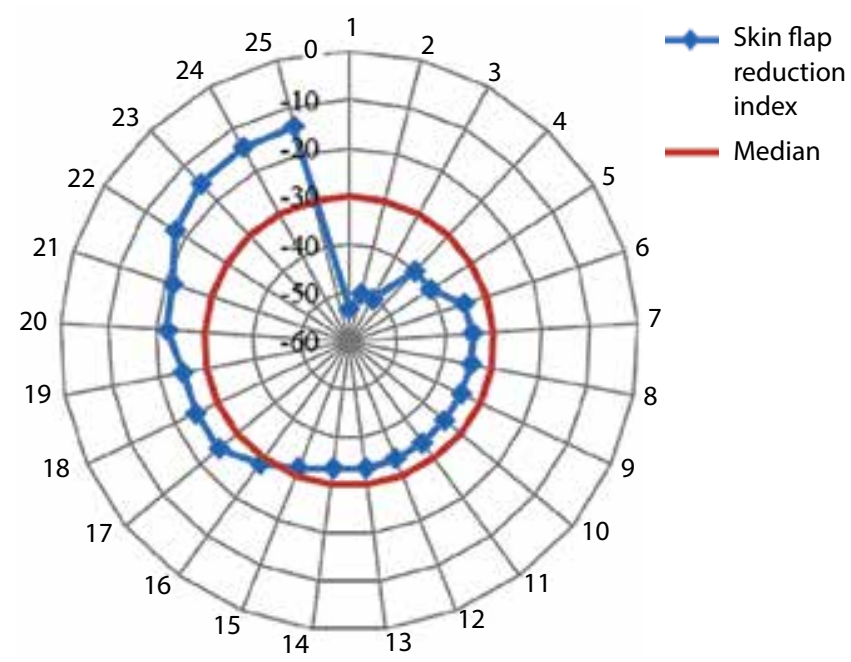

Fig. 1. Skin flap reduction index

Table 2. The size of resection margin depending on localization of position of the primary tumor $(n=174)$

\begin{tabular}{|c|c|c|c|c|}
\hline Resection margin & Hairy part of the head $(n=53)$ & Facial area $(n=90)$ & Regions of neck $(n=31)$ & Overall $(n=174)$ \\
\hline$<0.5 \mathrm{~cm}$ & $11(20.8 \%)^{*}$ & $44(48.9 \%)$ & $2(6.4 \%)^{*}$ & $57(32.8 \%)$ \\
\hline $0.6-1.0 \mathrm{~cm}$ & $16(30.2 \%)$ & $30(33.3 \%)$ & $18(58.1 \%)^{* \dagger}$ & $64(36.8 \%)$ \\
\hline$>1.0 \mathrm{~cm}$ & $26(49.0 \%)^{*}$ & $16(17.8 \%)$ & $11(35.5 \%)^{*}$ & $53(30.4 \%)$ \\
\hline Average, cm & $1.04 \pm 0.63^{*}$ & $0.61 \pm 0.41$ & $1.02 \pm 0.50^{*}$ & $0.82 \pm 0.54$ \\
\hline \multicolumn{5}{|c|}{$\begin{array}{l}\text { * Significant difference compared to the position of the tumor in the facial area. } \\
+ \text { Significant difference compared to the position of the tumor in the hairy part of the head. }\end{array}$} \\
\hline
\end{tabular}


often recorded in the neck area $-58.1 \%(n=18)$ compared to hairy part of the head and facial area: 30.2 and $33.3 \%$, respectively $(p<0.005)$. Surgical resection margin of more than $1.0 \mathrm{~cm}$ was most often found in groups of patients with localization of the tumor on the hairy part of the head $49 \%$ $(n=26)$ and $35.5 \%$ of the neck $(n=11)$ (compared with the facial area $17.8 \%, p<0.005)$.

When localizing the tumour in the facial area, the average resection margin value constituted $0.61 \pm 0.41$ and was significantly smaller (compared to the hairy part of the head $1.04 \pm 0.63(p=0.000002)$ and the neck area $1.02 \pm 0.50$ $(p=0.000017)$.

Since the thickness of the tumor according to Breslow is the most important prognostic factor for the local cutaneous melanoma, we analyzed the size of the surgical resection margin depending on the thickness of the primary melanoma, and the following tendency was detected. In the group of patients with "thin" melanoma $(\leq 1 \mathrm{~mm})$, in most cases the minimum $(<0.5 \mathrm{~cm})$ surgical resection margin was performed $-16(55 \%)$, a bit less often $0.6-1.0 \mathrm{~cm}-11$ (38\%), and margin $>1.0 \mathrm{~cm}$ in only $2(7 \%)$ patients (table 3). A detailed analysis of patients with a surgical margin tumor thickness (1.01-2.00 and 2.01-4.00 mm) showed almost the same distribution of patients in groups depending on the size of the surgical resection margin. At the same time, surgical resection margin of up to $1.0 \mathrm{~cm}$ was performed in these groups, in most cases (79 and $76.9 \%)$. In the group of patients with "thick" cutaneous melanoma $(>4 \mathrm{~mm})$, the maximum surgical margin $(>1.0 \mathrm{~cm})$ was performed with $41(41.5 \%)$ patients, and twice less often -22 times $(22.2 \%)$ - the minimum one was $(<0.5 \mathrm{~cm})$.
Also, all the patients were divided into two groups according to the presence or absence of ulceration of primary skin melanoma: $105(60.3 \%)$ against $68(39.1 \%)$ (table 4).

It is common knowledge, that the presence of metastasis in regional lymphatic nodes $(\mathrm{pN}+)$ is one of the main factors which significantly worsens the followed-up treatment results of patients with cutaneous melanoma. For that matter, for obtaining an objective assessment of the impact of such a factor as the size of the surgical resection margin, we decided to exclude patients with regional metastasis from the study groups for further analysis. Thus, the group without regional metastasis ( $\mathrm{pN} 0)$ constituted 131 patients.

A detailed analysis of the surgical resection margin depending on the stage of TNM/AJCC (the distribution was performed in the group without regional metastasis "pN0") generally showed a similar tendency, as when analyzing the general group of patients with surgical resection margin depending on the thickness of the tumor according to Breslow $(n=174)$ (table 3 ). Surgical resection margin $\leq 0.5 \mathrm{~cm}$ was most often performed at the stage of melanoma 0 - IA/B $41.6 \%$ (table 5). In stages IIA and IIB, all types of surgical resection margin were used approximately similarly often. The maximum surgical resection margin $(>1.0 \mathrm{~cm})$ was most often ( 3 times) used in the IIC stage of the tumor process.

Thus, a greater surgical resection margin was used with a greater local prevalence of the tumor process.

In order to determine the reference range of the necessary resection margin that affects the prognosis of the disease course, we analyzed the ROC curves (Receiver Operating Characteristic) at different tumor thicknesses in relation to the frequency of progression (fig. 2).

Table 3. The size of the surgical resection margin depending on the thickness of the tumor according to Breslow $(n=174)$

\begin{tabular}{|c|c|c|c|c|c|}
\hline \multirow{2}{*}{$\begin{array}{c}\text { Resection } \\
\text { margin }\end{array}$} & \multicolumn{5}{|c|}{ Thickness of the tumor according to Breslow } \\
\hline & $\leq 1 \mathrm{~mm}(n=29)$ & $1.01-2.00 \mathrm{~mm}(n=19)$ & $2.01-4.00 \mathrm{~mm}(n=26)$ & $>4 \mathrm{~mm}(n=99)$ & in situ $(n=1)$ \\
\hline$<0.5 \mathrm{~cm}$ & $16(55.0 \%)^{*}$ & $9(47.5 \%)^{*}$ & $9(34.6 \%)$ & $22(22.2 \%)$ & $1(100.0 \%)$ \\
\hline $0.6-1.0 \mathrm{~cm}$ & $11(38.0 \%)$ & $6(31.5 \%)$ & $11(42.3 \%)$ & $36(36.3 \%)$ & $0 \%$ \\
\hline$>1.0 \mathrm{~cm}$ & $2(7.0 \%)^{*}$ & $4(21.0 \%)$ & $6(23.1 \%)$ & $41(41.5 \%)$ & $0 \%$ \\
\hline
\end{tabular}

* Significant differences compared to a tumor with thickness more than $4 \mathrm{~mm}$.

Thus, with an increase in the thickness of the tumor, the size of the surgical resection margin gradually increased.

Table 4. Patient distribution according to ulceration

\begin{tabular}{|l|c|c|c|c|}
\hline \multicolumn{1}{|c|}{ Ulceration } & Hairy part of the head $(\boldsymbol{n}=\mathbf{5 3})$ & Facial area $(\boldsymbol{n}=\mathbf{9 0})$ & Neck area $(\boldsymbol{n}=\mathbf{3 1})$ & Total $(\boldsymbol{n}=\mathbf{1 7 4})$ \\
\hline No & $17(38.1 \%)$ & $39(43.3 \%)$ & $12(38.7 \%)$ & $68(39.1 \%)$ \\
\hline Yes & $36(67.9 \%)$ & $50(55.6 \%)$ & $19(61.3 \%)$ & $105(60.3 \%)$ \\
\hline In situ & $0 \%$ & $1(1.1 \%)$ & $0 \%$ & $1(0.6 \%)$ \\
\hline
\end{tabular}


Table 5. The amount of surgical resection margin depending on the stage of cutaneous melanoma in the pNO group $(n=131)$

\begin{tabular}{|c|c|c|c|c|c|}
\hline \multirow{2}{*}{ Resection margin } & \multirow{2}{*}{ Amount of patients } & \multicolumn{4}{|c|}{ Stage of TNM/AJCC } \\
\hline & & $0-$ IA/B & IIA & IIB & IIC \\
\hline$\leq 0.5 \mathrm{~cm}$ & 48 & $20(41.6 \%)$ & $7(14.6 \%)$ & $13(27.1 \%)$ & $8(16.7 \%)$ \\
\hline $0.5-1.0 \mathrm{~cm}$ & 51 & $11(21.6 \%)^{*}$ & $7(13.7 \%)$ & $13(25.5 \%)$ & $20(39.2 \%)^{*}$ \\
\hline$>1.0 \mathrm{~cm}$ & 32 & $3(9.4 \%)^{*}$ & $3(9.4 \%)$ & $9(28.1 \%)$ & $17(53.1 \%)^{*}$ \\
\hline Total & 131 & $34(25.9 \%)$ & $17(13.0 \%)$ & $35(26.7 \%)$ & $45(34.4 \%)$ \\
\hline
\end{tabular}
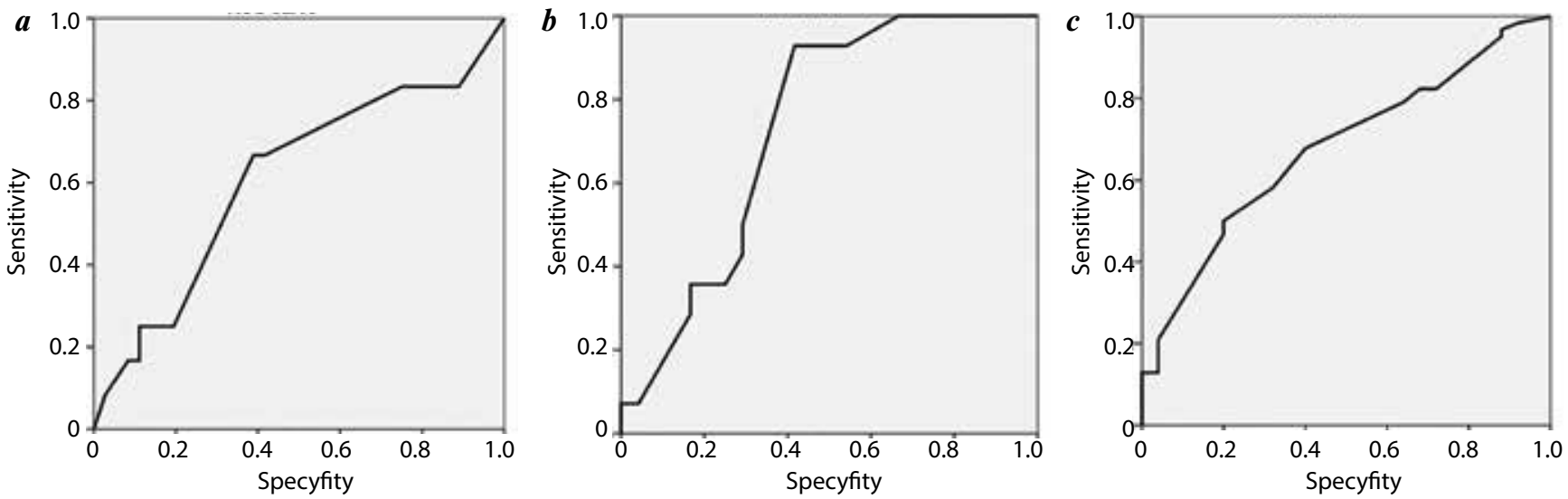

Fig. 2. ROC-curve for the thickness of tumor: $a$-less $2 \mathrm{~mm} ; b-2.01-4.0 \mathrm{~mm} ; \mathrm{c}-$ more than $4 \mathrm{~mm}$

The information from the ROC-curves was as follows. For thickness less than $2 \mathrm{~mm}$, the critical point was the resection margin value of $0.46 \mathrm{~cm}$, which turned out to be statistically insignificant, the sensitivity of this one was $67 \%$ with a specificity of $61 \%$ (fig. $2 a$ ). For the thickness of the primary tumor $2.01-4.00 \mathrm{~mm}$ (fig. $2 b$ ) and more than $4 \mathrm{~mm}$ (fig. $2 c$ ), the critical points became $0.58 \mathrm{~cm}$ (sensitivity $93 \%$ with a specificity of $58 \%$ ) and $0.72 \mathrm{~cm}$ (sensitivity $68 \%$ at specificity of $60 \%$ ), these indicators were significant.

The progression rate with a tumor thickness less than $2 \mathrm{~mm}$ with a surgical resection margin of up to $0.46 \mathrm{~cm}$ was $16.0 \%(n=4)$, and with more than $0.46 \mathrm{~cm}$ it was $34.8 \%$ $(n=8)(p=0.13)$. With a melanoma thickness of 2.01$4.0 \mathrm{~mm}$ with a surgical resection margin of up to $0.58 \mathrm{~cm}$, progression occurred in $6.7 \%(n=1)$ with more than $0.58 \mathrm{~cm}-56.5 \%(n=13)(p=0.002)$. And finally, with a tumor thickness of more than $4 \mathrm{~mm}$ with a surgical margin of up to $0.72 \mathrm{~cm}$, progression was noted in $57.1 \%(n=20)$, and with an surgical margin of more than $0.72 \mathrm{~cm}-80.8 \%$ $(n=42), p=0.016$.

Thus, it is seen that the increase of a surgical resection margin does not improve followed-up treatment results. An increase in significance was noted with an increase in the thickness of primary melanoma. This suggests that the influence of surgical resection margin is most important for cutaneous melanoma of $>2 \mathrm{~mm}$.

\section{Results}

While analyzing the followed-up treatment results in the general group of patients $(n=174)$, progression at different timescales after the end of treatment occurred in $51 \%$ of the cases (fig. 3). And this progression is most often

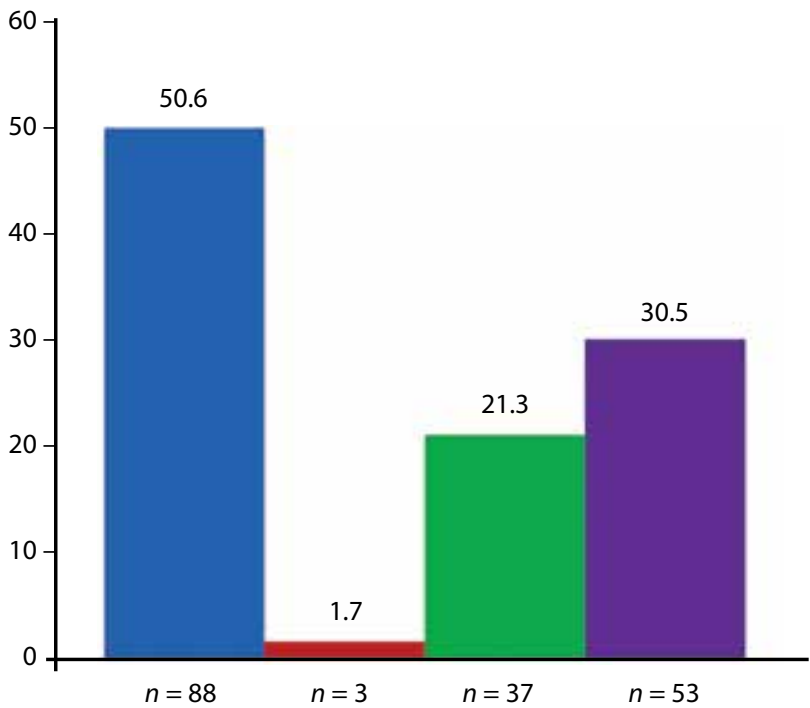

Fig. 3. Followed-up treatment results in the general group of patients $(n=174)$ 
manifested in the form of implementation of distant $(30.5 \%)$ and regional $(21 \%)$ metastasis. And only in $2 \%$ $(n=3)$ of cases the occurrence of local recurrence was recorded.

For further understanding of the influence of surgical resection margin on followed-up treatment results and for obtaining more objective data from the study group, patients with regional $\mathrm{pN}+$ metastases were excluded; therefore, the study was performed in the group without regional $\mathrm{pN} 0$ metastases $(n=131)$.

Among the 131 of analyzed patients, progression occurred to $55(42.0 \%)$ patients in the period from 1 to 121 months (the average time of progression constituted $18.7 \pm 23.6$ months). The age of patients ranged from 20 to 89 years (mean age $53.3 \pm 15.9$ years, median 54 years). 47 (35.8\%) patients died from the underlying disease. They were tracked in the

Cumulative Proportion Surviving (Kaplan-Meier)

o Progression + No progression

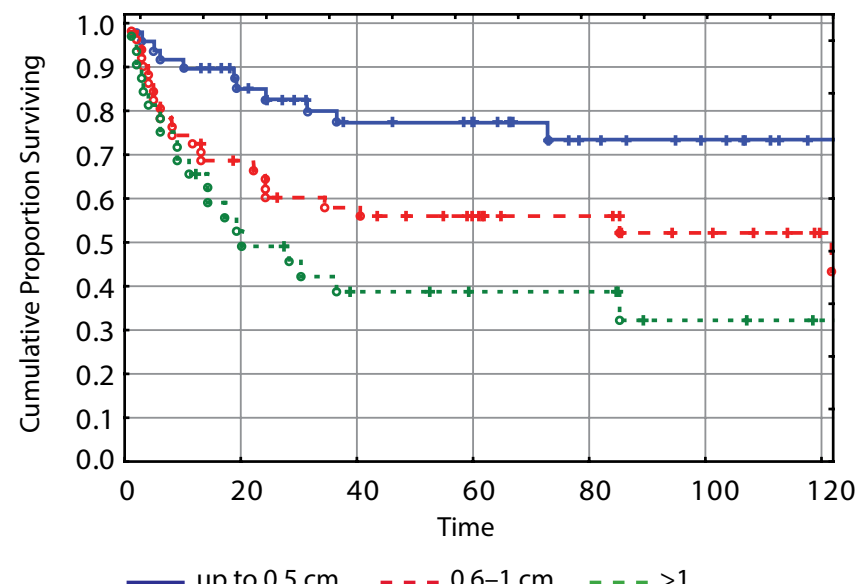

Fig. 4. Recurrence-free survival curve depending on the size of the surgical resection margin in the group of patients without regional metastases ( $p \mathrm{NO}$, $n=131, p=0.0022$ ) period from 7.3 to 190.4 months (average period of monitoring constituted $65.1 \pm 45.2$ months, median 59.3 months).

Recurrence-free survival did not correlate with the size of the surgical resection margin. It was the best with a minimal resection margin of $77.3 \pm 6.4 \%$ (median not achieved) and the worst with a maximum surgical margin of $38.7 \pm 8.8 \%$ (median of 20 months) (fig. 4), that means, that followed-up treatment results did not depend on the increase in the width of the surgical resection margin.

During the detailed analysis of the "N0" group, depending on the size of the surgical resection margin, it turned out that with an increase of surgical margin, the frequency of progression of patients rapidly grew (fig. 5). So, with surgical margin of $\leq 0.5 \mathrm{~cm}$, progression occurred in $22.9 \%$, $0.6-1.0 \mathrm{~cm}-47 \%(p<0.05)$ and with surgical margin more than $>1 \mathrm{~cm}-62.5 \%(p<0.05)$. This happened mainly due to an increase in the frequency of regional and distant metastasis process. Regional metastases with a minimum indentation $(\leq 0.5 \mathrm{~cm})$ were realized in $10.4 \%$, while with a maximum surgical resection margin $(>1 \mathrm{~cm})$ this indicator was $37.5 \%$. A similar tendency is observed when assessing the frequency of distant metastasis process: $\leq 0.5 \mathrm{~cm}-$ $12.5 \%$, and at $>1 \mathrm{~cm}-25 \%$, respectively. It is important to note that local recurrence of cutaneous melanoma over the entire observation period developed in $2(3.9 \%)$ patients with a surgical indentation of $0.6-1.0 \mathrm{~cm}$. Thus, it can be seen that the area of the surgical resection margin does not affect the frequency of local recurrence.

The frequency of regional and distant metastases in the group of patients with a tumor thickness of more than $4 \mathrm{~mm}$, increased by more than 3 times compared to the group of patients with up to $1 \mathrm{~mm}$ one (fig. 6). Moreover, the frequency of local recurrence did not depend on the thickness of the primary tumor according to Breslow.

In the group of patients with V-level of invasion, the frequency of regional and distant metastasis also sharply increased compared to the group of patients with II level (fig. 7).

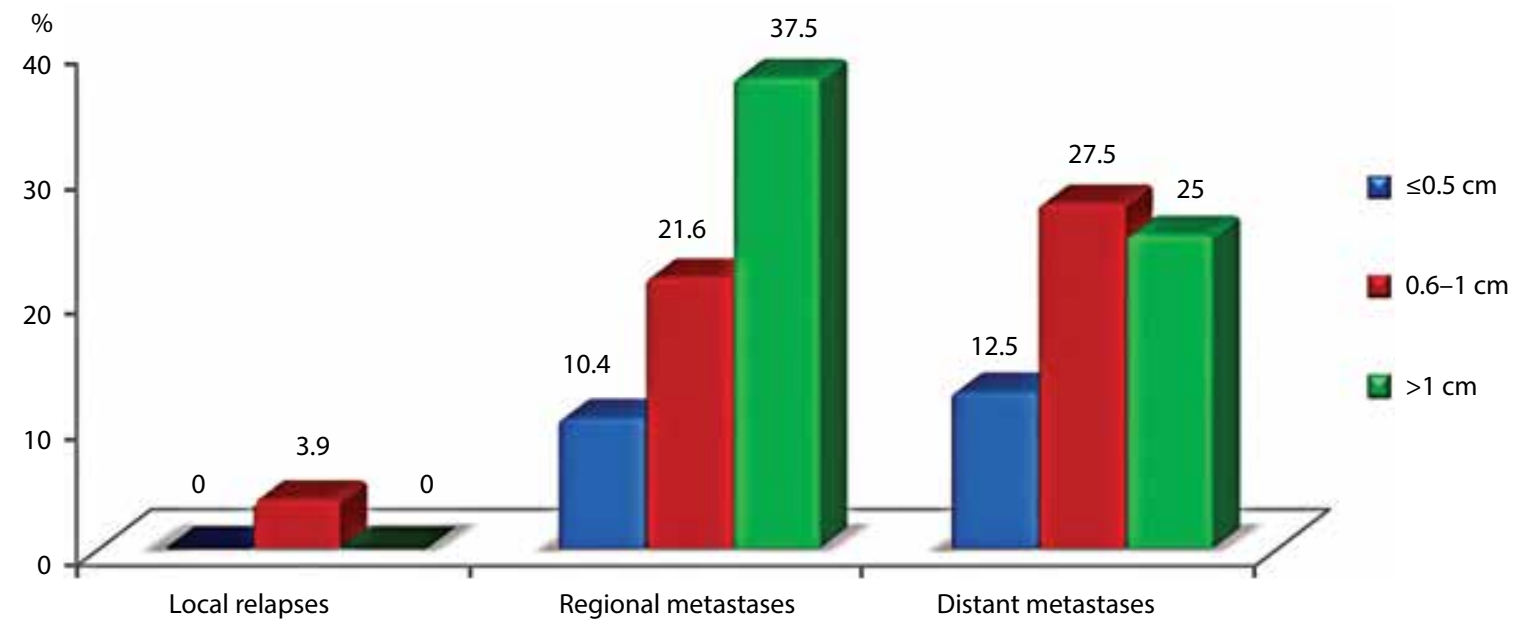

Fig. 5. Followed-up treatment results depending on the size of the surgical resection margin in the group of patients without regional metastases ( $p N 0, n=131)$ 


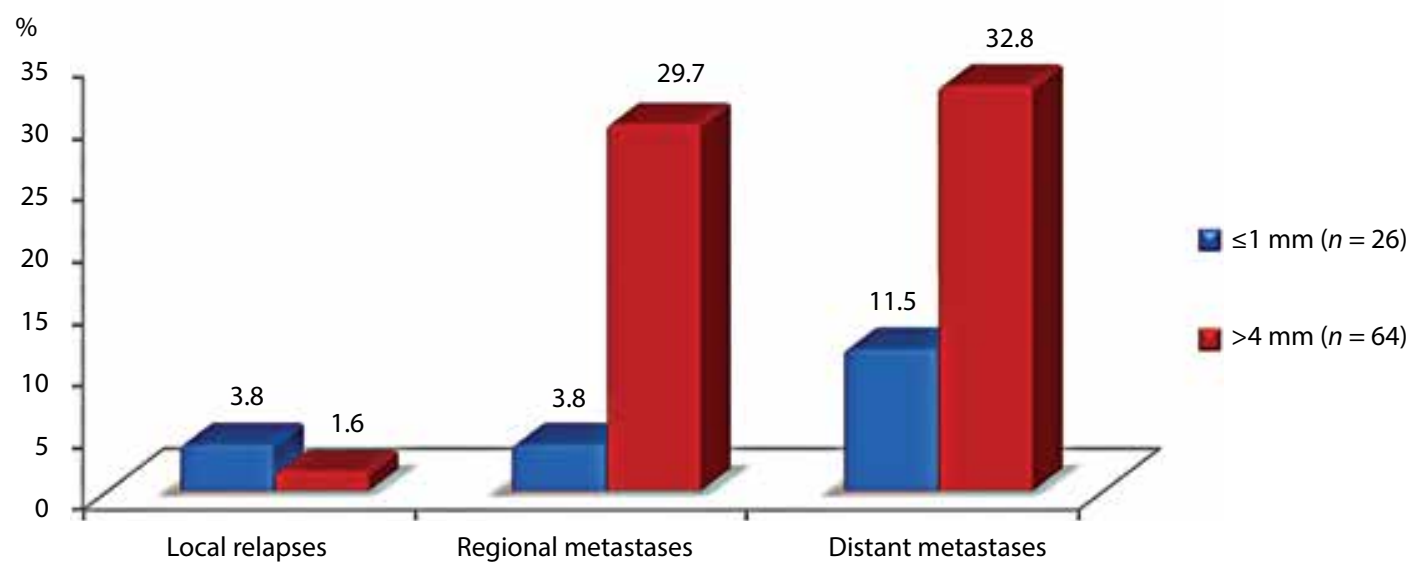

Fig. 6. Followed-up treatment results depending on the thickness of melanoma according to Breslow in the group of patients without regional metastases $(p N 0, n=131)$

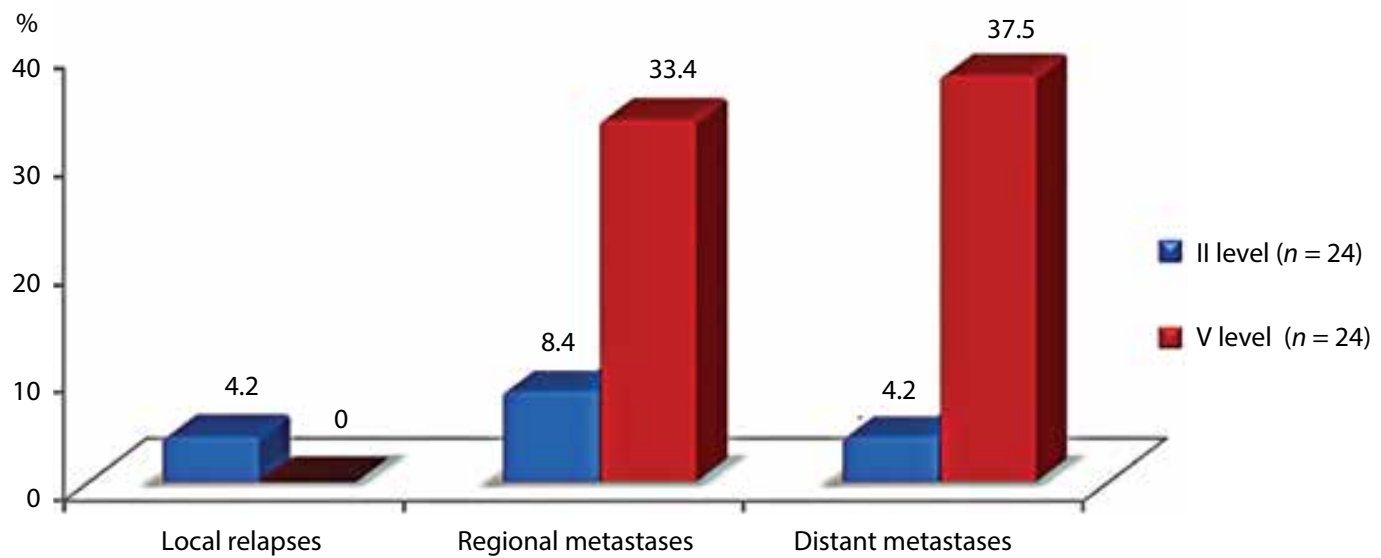

Fig. 7. Followed-up treatment results depending on the level of invasion according to Clark in the group of patients without regional metastases ( $p N 0, n=131)$

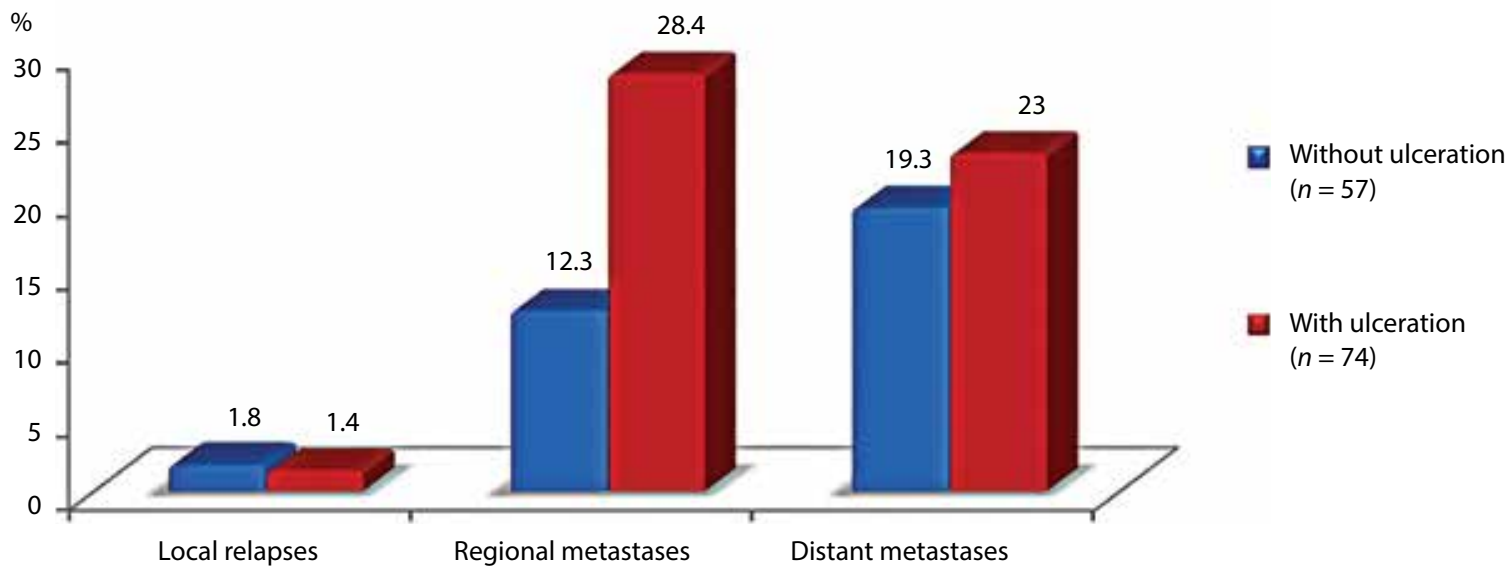

Fig. 8. Followed-up treatment results depending on the presence of ulceration in the group of patients without regional metastases $(p N 0, n=131)$

There was still no effect of the invasion level according to Clark on the local recurrence rate.

During the analysis of followed-up treatment results, depending on such an important prognostic factor as carcinelcosis of the primary tumor, it can be seen that worsening of overall survival occurred also due to an increase in the frequency of regional and distant metastasis (fig. 8). It should be noted that the frequency of regional metastases 
in the group with carcinelcosis of the primary tumor increased by more than $50 \%$. At the same time, no influence of this factor on the frequency of local recurrence was noted.

\section{Discussion}

The current study shows that cutaneous melanoma of head and neck is not characterized as a disease of local recurrences but manifests itself in the form of high frequency regional and distant metastases, which fits into the nature of tumor biology. Local recurrences can be affected not only by surgical resection margin and pathomorphological prognostic factors such as tumor thickness according to Breslow, level of invasion according to Clark, ulceration, as well as the tumor biology, which makes the further studies within the prospective multicenter research incredibly relevant.

The present study demonstrates that cutaneous melanoma of head and neck is not a disease of local recurrences, but it manifests itself in the form of a high frequency of regional and distant metastases, which fits into specificity of tumor biology. The local recurrence can be affected not only by surgical resection margin and pathomorphological prognostic factors such as tumor thickness according to Breslow, level of invasion according to Clark and the presence of ulceration, as well as the biology of the tumor itself, which makes the question of further study, within the framework of a prospective multicenter study, incredibly relevant.

\section{Conclusions}

We consider that clear surgical margins for any thickness of cutaneous melanoma of head and neck should be as follows: $<2 \mathrm{~mm}-0.46 \mathrm{~mm}(p=0.13), 2.01-4.00 \mathrm{~mm}-$ $0.58 \mathrm{~mm}(p=0.002),>4 \mathrm{~mm}-0.72 \mathrm{~mm}(p=0.016)$.

In our work, the influence of the main prognostic factors, such as tumor thickness according to Breslow, level of invasion according to Clark and ulceration on the frequency of head and neck cutaneous melanoma local recurrences had no impact.

\section{R E}

1. Аллахвердян Г.С., Чекалова М.А., Кокосадзе Н.В. Дооперационная оценка местного распространения первичной меланомы кожи ультразвуковым методом. Ультразвуковая и функциональная диагностика 2007;(4):238-9.

[Allakhverdyan G.S., Chekalova M.A., Kokosadze N.V. Preoperative assessment of the local spread of primary cutaneous melanoma using ultrasound. Ultrazvukovaya i funktsionalnaya diagnostika = Ultrasound and functional diagnostics 2007;(4):238-9. (In Russ.)].

2. Balch C.M., Soong S.J., Murad T.M. et al. A multi factorial analysis of melanoma. II. Prognostic factors in patients with stage I (localized) melanoma. Surgery 1979;86(2):343-51.

3. Пачес А.И. Опухоли головы и шеи: Клиническое руководство. М.: Практическая медицина, 2013. С. 60-69. [Paches A.I. Head and neck tumors: Clinical guideline. Moscow: Prakticheskaya meditsina, 2013. P. 60-69. (In Russ.)].

4. Friedman R.J., Rigel S., Kopf A.W. Early detection of malignant melanoma: the role of physician examination and self-examination of the skin. CA Cancer J Clin 1985;35(3):130-51. DOI: $10.3322 /$ canjclin.35.3.130.

5. Friedman R.J., Rigel D.S., Silverman M.K. et. al. Malignant melanoma in the 1990's: The continued importance of early detection and the role of physician examination and self-examination of the skin. CA Cancer J Clin 1991;41(4):201-26. DOI: 10.3322/canjclin.41.4.201.

6. Rigel D.S., Kopf A.W., Friedman R.J. The rate of malignant melanoma in the United States: are we making an impact?
J Am Acad Dermatol 1987;17(6):1050-3. DOI: 10.1016/s0190-9622(87)80487-5.

7. Малишевская Н.П., Соколова А.В., Демидов Л.В. Современное состояние заболеваемости меланомой кожи. Медицинский совет 2018;(10):161-5. [Malishevskaya N.P., Sokolova A.B., Demidov L.V. The incidence of skin melanoma in the russian federation and federal districts. Meditsinsky sovet $=$ Medical Council 2018;(10):161-5. (In Russ.)].

8. Balch C.M., Hjugton A.N., Peters L.I. Cutaneous melanoma. In: Principles and practice of oncology. Ed. by V.I. De Vita, S. Hellman, S.A. Rosenberg. $4^{\text {th }}$ edn. Philadelphia: Lippencott Co., 1993. P. 1612-1661.

9. Elder D.E., Guerry D.V., Heiberger R.M. et al. Optimal resection margin for cutaneous malignant melanoma. Plast Reconstr Surg 1983;71(1):66-72. DOI: 10.1097/00006534-198301000-00015.

10. Bodurtha A.J. Spontaneous regression of malignant melanoma. In: Human malignant melanoma. Ed. by W.H. Clark, L.J. Goldmarm, M.J. Mastrangelo. New York; San Francisco; London: Game \& Stratton, 1979. P. 227-241.

11. Spellman J.E. Jr, Driscoll D., Velez A., Karakousis C. Thick cutaneuos melanoma of the trunk and extremities: an institutional review. Surg Oncol 1994;3(6):335-43. DOI: 10.1016/0960-7404(94)90072-8.

12. Taylor B.A., Hughes L.E. A policy of selective excision for primary cutaneous malignant melanoma. Eur J Surg Oncol 1985;11(1):7-13.

13. Urist M.M., Balch C.M., Soong S.J. et al. Head and neck melanoma in 534 clinical stage I patients. A prognostic factors analysis and results of surgical treatment. Ann Surg 1984;200(6):769-75.

DOI: 10.1097/00000658-198412000-00017.

14. Urist M.M., Maddox W.A., Kennedy J., Balch C.M. Patient risk factors and surgical morbidity after regional lymphadenectomy in 204 melanoma patients. Cancer 1983;51(11):2152-6.

15. Анисимов В.В. Содержание понятия «местный рецидив» после хирургического лечения злокачественной меланомы кожи. Вопросы онкологии 1985;31(1):32-7. [Anisimov V.V. Content of the concept of "local recurrence" after surgical treatment of cutaneous malignant melanoma. Voprosy onkologii $=$ Problems in Oncology 1985;31(1):32-7. (In Russ.)].

16. Трапезников Н.Н., Рабен А.С., Яворский В.В., Титинер Г.Б. Пигментные невусы и новообразования кожи. М.: Медицина, 1976. С. 177. [Trapeznikov N.N., Raben A.S., Yavorski V.V., Titiner G.B. Pigmented nevi and skin neoplasms. Moscow: Meditsina, 1976. P. 177. (In Russ.)].

17. Beardmore G.L., Davis N.C. Multiple primary cutaneous melanomas. Arch Dermatol 1975;11:603-9.

18. Cascinelli N., Bajetta E., Vaglini M. et al. Present status and future perspectives of adjuvant treatment of cutaneous malignant melanoma. Pigment Cell Res 1983;6:187-98.

19. Stage I melanoma of the skin: the problem of resection margins. W.H.O. Collaborating Centres for Evaluation of Methods of Diagnosis and Treatment of Melanoma. Eur J Cancer 1980;16(8):1079-85.

20. Day C.L., Harrist T.J., Gorstein F. et al. Prognostic significance of "microscopic 
satellites" in the reticular dermis and subcutaneous fat. Ann Surg 1981;194(1):108-12. DOI: 10.1097/ 00000658-198107000-00019.

21. Levine A. On the histological diagnosis and prognosis of malignant melanoma. J Clin Pathol 1980;33(2):101-24. DOI: $10.1136 /$ jcp.33.2.101.

22. Banzet P., Thomas A., Vuillemin E. Wide versus narrow surgical excision in thin $(<2 \mathrm{~mm})$ stage I primary cutaneous melanoma: long term results of a French multicentric prospective randomized trial on 319 patients. Proc Am Assoc Clin Oncol 1993;12:387.

23. Khayat D., Rixe O., Martin G. et al. Surgical margins in cutaneous melanoma ( $2 \mathrm{~cm}$ versus $5 \mathrm{~cm}$ for lesions measuring less than 2.1-mm thick). Cancer 2003; 97(8):1941-6. DOI: 10.1002/cncr.11272.

24. Cohn-Cedermark G., Rutqvist L.E., Andersson R. et al. Long term results of a randomized study by the Swedish Melanoma Study Group on 2-cm versus 5-cm resection margins for patients with cutaneous melanoma with a tumor thickness of $0.8-$ $2.0 \mathrm{~mm}$. Cancer 2000;89(7):1495-501.

25. Ringborg U., Andersson R., Eldh J. et al. Resection margins of 2 versus $5 \mathrm{~cm}$ for cutaneous malignant melanoma with a tumor thickness of 0.8 to $2.0 \mathrm{~mm}$ : randomized study by the Swedish Melanoma Study Group. Cancer 1996;77(9):1809-14.

26. Cascinelli N., Belli F., Santinami M. et al Sentinel lymph node biopsy in cutaneous melanoma: the WHO Melanoma Program experience. Ann Surg Oncol 2000;7(6):469-74.

DOI: $10.1007 / \mathrm{s} 10434-000-0469-z$.

27. Veronesi U., Cascinelli N. Narrow excision (1-cm margin). A safe procedure for thin cutaneous melanoma. Arch Surg 1991;126(4):438-41. DOI: 10.1001/ archsurg.1991.01410280036004.

28. Balch C.M., Urist M.M., Karakousis C.P. et al. Efficacy of 2-cm surgical margins for intermediate-thickness melanomas (1 to $4 \mathrm{~mm}$ ). Results of a multiinstitutional randomized surgical trial.

29. Ann Surg 1993;218(3):262-7. DOI: 10.1097/00000658-199309000-00005.

30. Balch C.M., Soong S.J., Smith T. et al. Long-term results of a prospective surgical trial comparing $2 \mathrm{~cm}$ vs. $4 \mathrm{~cm}$ excision margins for 740 patients with $1-4 \mathrm{~mm}$ melanomas. Ann Surg Oncol 2001;8(2):101-8. DOI: 10.1007/s10434-001-0101-x.

31. Karakousis C.P., Balch C.M., Urist M.M. et al. Local recurrence in malignant melanoma: long-term results of the multiinstitutional randomized surgical trial. Ann Surg Oncol 1996;3(5):446-52. DOI: 10.1007/BF02305762.

32. Thomas J.M., Newton-Bishop J., A'Hern R. et al. Excision margins in highrisk malignant melanoma. $\mathrm{N}$ Engl J Med 2004;350(8):757-66. DOI: 10.1056/NEJMoa030681.

33. Ringborg U., Brahme E.M., Drewiecki K. Randomized trial of a resection margin of $2 \mathrm{~cm}$ versus $4 \mathrm{~cm}$ for cutaneous malignant melanoma with a tumor thickness of more than $2 \mathrm{~mm}$. In: World Congress on Melanoma. Vancouver, 2005.

34. Wheatley K., Wilson J.S., Gaunt P., Marsden J.R. Surgical excision margins in primary cutaneous melanoma: a metaanalysis and Bayesian probability evaluation. Cancer Treat Rev 2016;42:73-81. DOI: 10.1016/j.ctrv.2015.10.013.

35. Breslow A. Thickness, cross-sectional areas and depth of invasion in prognosis of cutaneous melanoma. Ann Surg 1970;172:902-8.

36. Balch C.M., Houghton A.N., Sober A.J. et al. Thompson complex closures of melanoma excisions. In: Cutaneous melanoma. 5th edn. St. Louis: Quality Medical Publishing, 2009. P. 275-319.

37. Барчук Л.С. Хирургическое лечение меланом. Практическая онкология 2001;(34):30-6. [Barchuk L.S. Surgical treatment of melanoma. Prakticheskaya onkologiya $=$ Practical Oncology 2001;(34):30-6. (In Russ.)].

38. Bagley F.H., Cady B., Lee A. et al. Changes in clinical preservation and management of malignant melanoma. Cancer 1981;47:2126-34.

39. Gershenwald J.E., Scolyer R.A., Hess K.R. et al. Melanoma staging: Evidence-based changes in the American Joint Committee on Cancer eighth edition cancer staging manual. CA Cancer J Clin 2017;67(6):472-92. DOI: $10.3322 /$ caac. 21409 .

\section{Authors' contributions}

A.M. Mudunov: developing the research design, surgical treatment, scientific editing, scientific advice, article writing;

M.B. Pak: article writing, reviewing of publications on the article's theme, analysis of the obtained data, surgical treatment, assistance;

L.V. Demidov: developing the research design, scientific editing, scientific advice;

K.A. Baryshnikov: surgical treatment, assistance, patient supervision.

Вклад авторов

А.М. Мудунов: разработка дизайна исследования, проведение операций, научное редактирование, научное консультирование, написание текста статьи;

М.Б. Пак: написание текста статьи, обзор публикаций по теме статьи, анализ полученных данных, проведение операций, ассистирование;

Л.В. Демидов: разработка дизайна исследования, научное редактирование, научное консультирование;

К.А. Барышников: проведение операций, ассистирование, курирование пациентов.

ORCID of authors / ORCID авторов

A.M. Mudunov / А.М. Мудунов: https://orcid.org/0000-0002-0918-3857

M.В. Pak / М.Б. Пак: https://orcid.org/0000-0003-4546-0011

L.V. Demidov / Л.В. Демидов: https://orcid.org/0000-0002-8562-6082

K.A. Baryshnikov / K.А. Барышников: https://orcid.org/0000-0002-9532-4264

Conflict of interest. The authors declare no conflict of interest.

Конфликт интересов. Авторы заявляют об отсутствии конфликта интересов.

Financing. The work was performed without external funding.

Финансирование. Исследование выполнено без спонсорской поддержки.

\section{Compliance with patient rights and principles of bioethics}

The study protocol was approved by the biomedical ethics committee of I.M. Sechenov First Moscow State Medical University.

All patients gave written informed consent to participate in the study.

Соблюдение прав пациентов и правил биоэтики

Протокол исследования одобрен комитетом по биомедицинской этике Первого Московского государственного медицинского университета им. И.М. Сеченова.

Все пациенты подписали информированное согласие на участие в исследовании.

Статья поступила: 22.07.2020. Принята к публикации: 15.09.2020.

Article submitted: 22.07.2020. Accepted for publication: 15.09.2020. 